\title{
Farms as learning environment - experiences from school-farm co-operation
}

Helmi Risku-Norja ${ }^{1}$, Elli Korpela ${ }^{1,}$ Marja-Liisa Vieraankivi ${ }^{2}$

${ }^{1}$ MTT Economic Research, 31600 Jokioinen,

${ }^{2}$ MTT Biotechnology and Food Research 31600 Jokioinen, first name.surname@mtt.fi

\section{Tiivistelmä}

Maalle oppimaan - maaseutulähtöisen ympäristökasvatuksen verkosto Suomessa ja Virossa on yhteistyöhanke, jossa on kehitetty paikallistason yhteistyötä koulujen ja maatilojen välillä. Tavoitteena on edistää kestävää kehitystä kiinnittämällä huomio erityisesti lapsiin ja nuoriin. Hankkeen toivotaan lisäävän heidän tietouttaan kulttuurin ja luonnon keskinäisestä vuorovaikutuksesta, vahvistavan siteitä koulun ja sen lähiympäristön välillä sekä luovan uusia toimintamalleja maaseutulähtöiseen kestävän kehityksen kasvatukseen.

Suomessa hankkeen tutkimusosiossa on tarkasteltu paikallistason koulumaatilayhteistyön toteutettavuutta, sen soveltuvuutta maatilojen toimintaan ja koulujen opetussuunnitelmaan sekä mahdollisuuksia kehittää yhteistyötä molempia osapuolia hyödyttävällä tavalla, opetussuunnitelman suuntaviivojen mukaisesti. Tutkimukseen osallistui kymmenen luokkaa peruskoulun alaluokilta. Koulut lähimaatiloineen sijaitsivat Vihdissä, Forssassa, Tammelassa ja Jokioisilla. Koululaiset vierailivat maa- tai metsätilalla opettajan ja maatilayrittäjän yhdessä suunnitteleman ohjelman mukaisesti ja osallistuivat tilan arkipäivään. Tutkimusaineisto kerättiin tarkkailemalla toimintaa, haastattelemalla mukana olevia opettajia ja yrittäjiä sekä opettajien päiväkirjojen avulla.

Tulokset osoittavat, että paikallistason koulu-maatilayhteistyö on kiinnostava mahdollisuus sekä maatiloille että kouluille. Maatilayrittäjälle yhteistyö on ennen kaikkea oivallinen tilaisuus suhdetoimintaan. Tutkimukseen osallistuville tiloille maksettiin oppilaiden lukumäärään perustuva korvaus vaivannäöstä. Oppilaat puolestaan saivat mieleenpainuvia elämyksiä maatilalta ja oppivat omakohtaisten kokemusten kautta maatilan arjesta ja työtavoista.

Opetus maatilalla oli helposti hyödynnettävissä koulun useissa oppiaineissa ja aihekokonaisuuksissa. Opettajat pitivät koulu-maatilayhteistyötä erittäin myönteisenä kokemuksena, joka kannattaisi kirjata koulun opetusohjelmaan. Opettajien mukaan oppilaat oppivat maatiloilla elämästä tavalla, jota eivät mitkään kirjat tai koulussa annettava opetus voi korvata. 


\section{Background}

In the modern, technology based service society the citizens have become gradually detached from the basic facts and praxis of life and living. In the information society the personal experiences are increasingly based on virtual reality and on the services of the commercial adventure production. People in general, children and the young especially are losing their ties to rural areas and rural culture, as well as to agriculture. Food is global, and consequently its route from field via fork back to field is blurred, as are the associated processes and impacts. The phenomenon is not restricted to the big cities, but is met increasingly also in the countryside. The balanced interaction between man and nature in general is blurred.

The task of the school is to prepare the pupils to become active citizens who are able to make conscious decisions about the matters concerning their own lives. The schools should provide the pupils with the basic knowledge and skills in various school subjects, and at the same time they have to keep pace with the information flow. With the knowledge increasing in an accelerating tempo, this is a real challenge. Modern life requires also dialogue between school and society; information needs to be considered in relation to the social reality which the school is part of. This widens the perspective, and often the disciplinary borders between the school subjects are crossed. In addition, the UN has devoted the ongoing decade 2004-2013 to sustainability education. Through the governmental agenda this increases the pressure for the schools.

The new national curriculum for basic education stresses the links between the school and the world outside the school by integrating the teaching through broad thematic entities ${ }^{1}$ (OPH 2004). Using the integrative approach the pupils are made to consider from different points of view the matters and phenomena tangential to their own lives. The aim is to help the analysis of the multifacetted and controversial phenomena of the present day world and, thus, to contribute to their objective and critical evaluation. The integrative education supports the growing of the pupils into active citizens by highlighting the interaction between human activity and the phenomena of the world.

The cross-curricular approach is a welcome innovation, but at the same time it requires a lot from the teachers, who have been given only a very general idea of what it means, but no concrete tools how to proceed and apply it in teaching.

In Finland the share of agriculture from the gross national product is only about one per cent, and its share from the employed labour force is about $3 \%$ (Statistics Finland 2005). It is clear that in a society where the status is based mainly on the economic performance, agriculture is not valued especially high. The farms have also other challenges which are linked to the increasingly tight international competition. Within the Finnish agriculture, there is a survival struggle going on, and the sector is becoming strongly polarised. The area of cultivated land has been stabilised to about 2 million hectares, but the farmland is being redistributed. At the same time when the number of farms is decreasing, the number of large farms (over 100 hectares) has rapidly increased (MMM 2003)and, consequently, the average farm size has increased. The change is evident in specialisation and concentration of production both at the farm and regional level (Niemi \& Ahlstedt 2006). Nevertheless, the majority of the farms are still family farms, and these are struggling for survival. In contrast to the trend of increasing specialisation and concentration, the diversification of the farms has been also rising lately; from 2000 to 2005 the increase in the number of the diversified farms has been 11\% (Niemi \& Ahlstedt 2006). In relation to the diversified farms, farming is not the sole income source, but there are other activities as well, i.e. farming is part-time and there are incomes from working outside the farm (Jervell 1999). Pluri-activity has gained foothold especially among those farmers who for one reason or the other have not entered into expanding, but who nevertheless want to continue on small scale farming and living on their own farm (Rantamäki-Lahtinen 2002).

\footnotetext{
1 "Responsibility for the environment, health and sustainable future”, Active citizenship and entrepreneurship”, Communication and media skills”, Growing as human being”, "Traffic and safety”, "Cultural identity and internationality”, "Man and technology”
} 
The problems, therefore, are the new pressures and educational demands the schools are exposed to, survival of the family farms and eroding appreciation of agriculture within the society. The School Goes to the Farm -project has taken the challenge by developing local co-operation between schools, farms and regional nature centres both in Finland and in Estonia, the leading principles of which are localness, continuity and active participation.

\section{Framework and aim of the research}

There are many ways of using a farm as learning environment. The practices vary from farm visits to maintenance of school garden plots on the farm to active participation in farm work and to farm camp schools. In some form farms are used in outside-classroom teaching in many schools, although the practices have not been necessarily recorded in the curricula (Risku-Norja 2006). The School Goes to the Farm -project focuses explicitly on local co-operation between schools and nearby farms.

The present study focuses on local co-operation between schools and farms located nearby, and deals with the applicability of farm-school co-operation and its suitability to the schools' curricula. The benefits and development needs are considered both from the schools' and entrepreneurs' point of view. There are no ready made teaching packages, but the farmer and the teacher plan the activity in mutual understanding and by paying attention both to the specific needs of the school and to the possibilities of the farm. In the co-operation, the farm provides the framework for the outside classroom teaching, and the teacher has the pedagogic responsibility.

Educational benefits are considered within the framework of comprehensive and contextual learning. Comprehensive learning means that knowledge, activity, emotions, senses and values are all involved in learning. In addition to concepts and knowledge, it acknowledges the focal role of personal experiences, emotions and social interaction for learning. Learning becomes a process in which emotions, empiria, esthetics, ethics, epistemology, "the 5 big E:s", are intermingled in a continuous flow (Venkula 1995, Venkula 2005).

Contextual learning on the other hand, means that the new things are learned by deepening and expanding the existing knowledge, so that the pupils are interested in the things to be learned and understand the links to the previous knowledge meaning that they are able to apply what they have learned in practical situations, in their everyday activity (Cantell \& Koskinen 2004).

Thus, beside the concepts and knowledge, personal experiences and emotions as well as the social interaction between people have also play a focal role in learning; personal experiences strengthen the sensibility and the empathy (e.g. Palmer 1998, Chawla 1999, Jeronen \& Kaikkonen 2001). Ethical principles are similarly necessary, as the values and norms are formulated according to them and they, therefore, define the attitudes towards the various questions (Jeronen 1995). In addition, one needs to know the means and channels of the citizen activity. Only then can the knowledge be concretised into practical actions for the benefit of something (Serageldin \& Steer 1996, Gretschel 2002, Åhlberg 2005).

The specific questions addressed in this study are suitability of the farm-school co-operation to the school's curriculum and to school's everyday life, pupils' attitudes towards farming and countryside, the impact of the pupils' experiences and experiential learning on the farm on pupils' knowledge, learning and on their attitudes towards farms and countryside, teachers' and farmers' attitudes toward and opinions about farm-school co-operation and development needs to improve the suitability of such co-operation to the school's curriculum and to the farm's normal work.

\section{Methods}

The methods used in the study are qualitative. The reason to use this type of methods is the target of the research itself. When measuring opinions, attitudes and learning it is important to let the research material speak for itself instead of testing the hypothesis or theories (Hirsjärvi et al. 1997). The approaches used to obtain material for the qualitative analysis were:

Teachers' diaries. The participating teachers had the most important role in the study. They kept a diary about the farm visits in view of the program's compliance with the school's curriculum and success in general. The teachers were asked to describe their expectations and feelings before the farm visits. They were also asked to list possible risks and threats in advance. After the farm days 
the teachers answered the activation questions. In addition they were asked to evaluate the importance of the day for the pupils and to evaluate the visits in general.

Teachers' group interview. After the program, the teachers took part in the group interview. The aim was to compile their experiences and ideas about farm-school co-operation and to further develop the activities. Group interview was seen as a necessary platform to allow brainstorm type of generation of ideas. Free expression was encouraged.

Farmers' interviews. The farmers were interviewed after the program in November 2007. The questions were sent beforehand and the interview was by telephone within two weeks after receiving the questionnaire. Additional information about the farmers' first impressions and experiences was obtained during the program while compiling the guidebook (Risku-Norja \& Aaltonen 2007).

Observation in the farm. During the farm visits, in addition to the teacher and farmer, there were one or two grown-up persons helping with the practicalities. One of them was the person from the research group, whose task was to observe the activities, the practical arrangements and the behaviour and responses of the pupils in the new learning environment.

The schools took part in the farm programs during the autumn 2006 and spring 2007. During that period each group had one to four visits with a defined learning theme for the visits. The research comprised ten school classes and their teachers and seven farms. In addition, the Häme Visitor Centre together with the Korteniemi Traditional Farm hosted one the class from Forssa.

The pupils were fourth to sixth graders, ranging in age from 10 to13 years, all together 146 pupils. All the participating classes were from municipal schools, and the pupils took part in the farm's normal work relating to the learning theme. The educational content of the farm days was tailored to each group by the teacher in conjunction with the farmer.

\section{Results}

Suitability to curriculum. The teachers had no difficulties in streamlining the farm visits with the goals of the school's curriculum. The subjects such as environmental knowledge and natural history, geography and biology are directly linked to the farm visits. The farm with its surroundings is often a meeting place of past and present, bringing thus life to history and to cultural heritage education. The farm program can be exploited as subtexts in most - if not all subjects, e.g. outdoor work and cycling/cross-country skiing to the farm is physical education, experiences can be revived by means of art, learning diaries strengthen pupils' ability to express themselves in written form and many kinds of examples with practical applicability for the different calculations to be used in mathematics.

School-farm co-operation concretises also the cross-curricular themes, especially the themes "Responsibility for the environment, health and sustainable future" and "Active citizenship and entrepreneurship", but also others. The activities of the program, working together, taking care of the animals and having collective responsibility for performance of the tasks is in itself an essential part of growing as human beings, the theme that otherwise is difficult to teach.

Among the things the pupils learned during the program the following were mentioned: farm animals, forestry, and different living environments like fields, meadows and shore, species recognition. The pupils learned farm terminology and about their own immediate surroundings, its nature and places of employment, the life span of local products as well as about everyman's rights and responsibilities. They learned to appreciate their own cultural heritage and to understand the basis of the sustainable development in their nearby surroundings. They became acquainted with the entrepreneur's life from inside and had practice in various kinds of work and in using different kinds of common tools of the farm.

In addition to the knowledge contents, there were other important aspects: participation taught the pupils responsibility about common matters in own immediate surroundings, they learned to take responsibility for own work and to behave in a proper way in different surroundings and with unfamiliar people and to respect nature. They also got practice of working in groups. "It is really a matter of teacher's attitude and activity. There is so much good in this type of program, so it is better to make it suit!" 
Suitability to school's everyday life in general. Taking part in the program was not a problem, if the co-operation and practical arrangements were planned in time. Organisation required both discussions with the farmer, informing the parents, agreeing with the kitchen about the packed lunch for the pupils and planning the transport to the farm. In the lower grade schools, the class teacher has usually the responsibility for most of the subjects taught. He or she can, therefore, fairly freely adjust the teaching to the schedule of the farm visits. If some of the lessons e.g. in language, music etc are taught by specialised teachers, mutual rearrangements among the teachers were necessary.

If the farm was close enough the pupils travelled there by bikes or used skis in the winter. Transport was easy also, if the farm could be reached by means of public transport. In schools, where other type of transport was necessary, access to the farm required extra money for the chartered bus or extra arrangements to transport the pupils in small cars.

However, taking part in the program was seen as worth the trouble, it provided the pupils' with a new learning environment, which was considered as realistic and real, and it brought about welcome change to the normal school routines both for the pupils and the teachers.

Pupils' attitudes towards farming and farm-school co-operation. The school groups in the program ranged from $4^{\text {th }}$ to $6^{\text {th }}$ graders, or 10 to 12 years in age. The youngest age groups were least reserved and least prejudiced. The $5^{\text {th }}$ graders had suspicions before the program started, and for them the farm was much more interesting than they had expected. The $6^{\text {th }}$ graders were most critical beforehand and some were complaining even in the farm. Yet, despite critical comments about using "child labour" and about rather "hanging around than working" in the farm, according to their teachers, they seemed to enjoy the work when the time came. Some of the older boys were complaining about going to the horse farm as they thought horses are a girlish thing, but in the end they were working in stables with the same enthusiasm as the girls.

In general the pupils were looking forward to the first farm visit. During the following visits they were eager to work and they worked devotedly. They said they liked it. The pupils seemed to enjoy the time in the forest as well, but there were also comments such as "not again" when another visit was agreed upon.

The $5^{\text {th }}$ graders were willing to work both in the pig house as well as in the forest. Even if they dreaded the smell of the pig house in the beginning, they did not want to leave the place after getting used to it. They were eager to go to the farm again, and only one of them got sick from the smell of the pig house. It was a new thing to the pupils how automated and mechanised the pig house was, and that the work did not only consist of spading and dirty work. They were a little shocked by the great number of pigs, but they still felt that the pigs' living conditions were good. It was good for pupils to see, what the farm work is and what happens in the farm. They realized that farmers really have to work hard and that they won't just get the money free from the EU.

The general impression was that the farm visits were emotionally appealing because of the animals, and the experience was only of a positive nature to the pupils. They also noticed that there is a lot of daily work to do in the animal farm. The forest probably requires more time for the pupils to become aware of such profound nature experiences, which are necessary to arouse pupils' interest to become acquainted with the possibilities the forest can offer.

The $4^{\text {th }}$ graders appeared to be the best age when it comes to judging the attitudes; the older pupils seemed to be more reserved in their expression. In some aspects like the smell and the boys' thoughts about the horses being something girlish, the attitudes clearly changed, and the first impressions of the pupils during the actual visits were more positive than they had expected beforehand. According to the teachers, however, few visits are too short a time to make farreaching conclusions.

Impact of the school-farm program on pupils' learning. The time the pupils spent on the farm was not used for outdoor lessons; instead the focus was in learning by doing with their own hands and together with the schoolmates. The pupils learned also about different types of farm and forest work, and concrete experiences helps to adopt and maintain practical skills.

The significance of the activities in the farm was in creating frames of references for later learning rather than in subject-specific knowledge. Another important aspect was that pupils learned perseverance, routines, continuity and patience. Today the pupils live in a "supermarket 
society”, where people can pick up new items from the shelves when they so like. Visiting the same place several times showed that things and matters need time to develop and to change and also own efforts.

Pupils learned to respect the life itself. Staying with the newborn lambs in total peace and quietness was deeply emotional experience. Working with animals in general was a very nurturing learning environment. Taking care of and caressing especially small animals taught the pupils responsibility for the helpless and fragile creatures and to defend them when necessary, an experience which hopefully will be transferred also to the mutual relationships among the pupils. Extremely cold winter weather in the forest taught pupils to respect the nature and the fact that we cannot always control the circumstances ourselves.

Teachers' opinions about the farm-school co-operation. The farm-school program was a positive experience also for the teachers. The interviews revealed that in the beginning also most of the teachers had some doubts about how they actually make it through the program, and some were worried about getting to the farm by bikes among the traffic. Teachers' expectations apparently were not tuned very high and therefore the children's eagerness was very rewarding, neither did the teachers have difficulties in communication and co-operation with the farmers. "It went better than I ever expected! Very positive experience to me, I am eager to develop it further -with the pupils and the farmer". The good start gives firm basis to develop the farm activities further. To the teachers' opinion the project transferred a realistic and positive picture of the farm to the local schoolchildren. This is important for farmers, as it creates positive attitudes toward farming.

The farm visits always worked best, when the group size was small. The teachers appreciated that the program was practical and hands-on activity. In farm the pupils were divided into small groups of four to six children, who took turns in working together with different things. The schedule was at times too tight for organising the work among the groups.

Being the path breakers the teachers felt that they also had quite a lot of extra work in planning and organising the program, active participation in other projects during the same term was out of the question. Reporting was also time-consuming. More advice from the project staff and support from the colleges would have been useful for teachers.

After the promising pilot phase experiment it is important to create continuity and regularity into this type of program. In order to secure the necessary human and monetary resources the program should be incorporated in the school's curriculum.

Farm entrepreneurs' opinions. The entrepreneurs were concerned in providing the pupils with relevant and correct information, counterbalancing prejudices and to contribute to positive attitude towards farming.

They wanted to arouse children's interest in farm work in order to in the long run secure continuity of farming. They also felt that it is very important to teach the children where the food comes from, so that they become aware of the significance of food and of food security and, thus, improve the appreciation of domestic food production. The farm entrepreneurs were happy and positively surprised when, after the farm visits the children spontaneously made contact and wanted to hear about the animals they had become acquainted with or just to chat.

The school visits brought welcome change to the farmers' otherwise rather steady everyday work. However, all the interviewed entrepreneurs shared the opinion that a successful farm visit requires a lot organisation and effort. This takes time, and therefore the farmers also expect that the pupils have been prepared properly, have proper clothing for weather and farm work and that the teacher has control of the behaviour of the group. A slight risk of animal diseases was mentioned as one of the possible drawbacks in the animal farms. The farmers stressed the importance of normal farm work and everyday routines in the co-operation; if the activity on the farm is too organised, it may give an unrealistic picture of farming.

It is important that the farmer and the teacher agree beforehand precisely upon the activities in the farm and have mutual understanding on what work needs to be completed. If the farmer has to patch up pupils' achievements or the work that was agreed upon is not done, the eagerness to welcome school groups decreases rapidly. Mutual feed-back already in the farm should be aimed at to avoid the situation that something is bothering one or the other party afterwards. 
In the pilot phase the participating farm entrepreneurs received a small compensation of $2 €$ per pupil per hour which was funded from the project. The number of the pupils varied from 15-25 and the time spent on the farm was 2 - 5 hours. This was considered as reasonable, even though the income is taxable. However, the money was not the main or the sole reason to take part, instead the farmers saw co-operation as an excellent public relations possibility. Nearly all of the entrepreneurs who took part in the pilot project recommend co-operation with schools also for other farmers in their acquaintance. Co-operation was considered especially suitable for small farms.

\section{Discussion}

The leading principles in the school-farm co-operation are locality, continuity and active participation. Locality means that the focus is in treasuring and improving community-based cohesion, and the co-operation is between schools and farms located nearby. Continuity refers not only to temporally enduring co-operation but also to continuity across the disciplinary borders of the school subjects in order to help the pupils understand the intermingling of the ecological, economic and socio-cultural aspects of sustainability. The principle of active participation exploits pupils' experiences, emotions and senses in teaching, stresses learning by doing and practical application of what is learned.

Local approach has increased interaction between school and the local community. Enduring co-operation allows long term planning so that the activities build up a coherent continuum for the different grades of the school, and are at the same time reasonable also in view of the farmer's needs. The principle of locality has improved children's knowledge about their home district, which is important for identity formation. It has also increased the commitment of both the farmers and the teachers.

Active participation and learning by doing with their own hands and together with other pupils allows the pupils to use their abilities and skills comprehensively and to learn through their own experiences. When learning is based on positive experiences and on concrete situations, even the difficult matters become understandable with practical examples. Learning becomes interesting, which is crucial in all learning. When education is tied to the local environment and community, the significance of what is learned is obvious and the pupils have possibility to apply what they have learned in practice. Education is situational and contextual, and it is spiced with emotions, personal experiences and collective activity. The personal experiences in the farm and in the forest provide pupils with a cognitive foundation making it easier to receive and assimilate new knowledge and information. It is up to the teacher's professional skills, probably also to coincidence, how these experiences can be utilised to support pupils' learning.

The school-farm co-operation allows combining the concepts of comprehensive learning and contextual learning applying the model to rural-based sustainability education (Figure 1). The personal experiences on the farm comprise both the physical and social levels, the farm and the surrounding nature, the people, their activity and the impacts on the local and societal level. These form using the different senses. New experiences arouse the interest, which is the key for thirst to know more. New knowledge has to be reconciled with the existing knowledge and evaluated against it. This initiates active knowledge processing. Interest, new knowledge, empirical activity and critical evaluation all shape and modify values and attitudes. This process creates the basis for conscious behaviour and choices, which take expression in practical life situations.

The national curriculum for basic education stresses interaction of the school and the society and beside the subject-specific goals pays attention also to cross-curricular thematic entities. Responsibility for the environment well-being and sustainable future, own roots, cultural heritage, entrepreneurship and growing as a human being are important themes, and these are easily incorporated into the activities in the farm. The farms, thus, provide an environment, where educational goals of the curriculum can be realised in a truly comprehensive way. When carefully planned the activities in the farm give the pupils a possibility to many-sided learning in compliance with the goals of the curriculum and provide an option for the normal class- room teaching. 


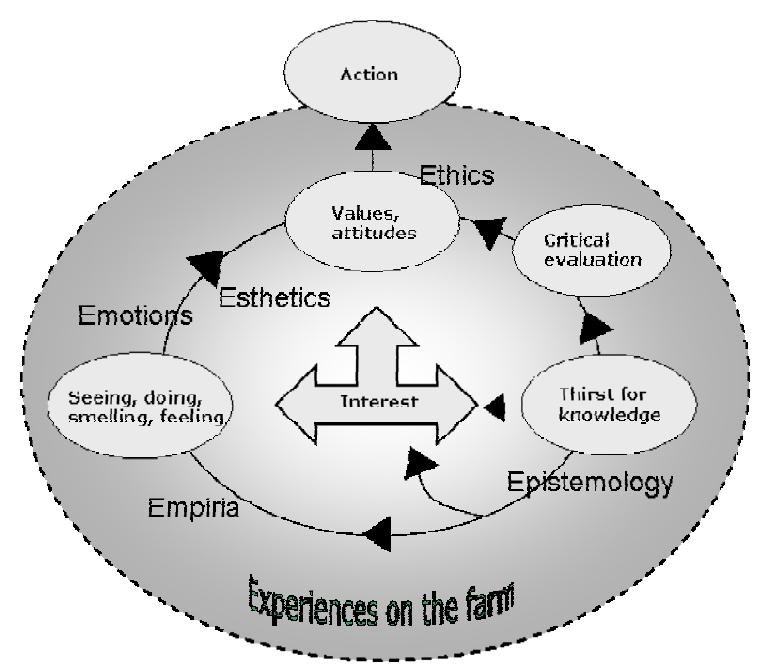

Figure 1. The educational basis for school-farm program is combined comprehensive and contextual learning.

The first experiences of both the teachers and farmers on co-operation are by and large positive. However, the evaluation of the benefits and drawbacks is based on a fairly short time span. Therefore, the positive opinions may probably be biased because of the charm of novelty, and the drawbacks because of the lack of practical routines in organising the co-operation.

Beside the specific subject matters, co-operation with the farms brings along also other aspects which the teachers value highly. Activities in the farm strengthen the co-operation skills of the children; they learn to work together, help each other and to take collective responsibility for the work. The pupils also learn to behave in a reasonable way in new situations and with new people. Taking care of the young animals is an emotional and particularly enriching experience. It teaches empathy and arouses the need to caress and to nurture. Such profound experiences are crucial for adopting ethical values and countryside, because children's experiences increase also understanding and knowledge among their parents.

For the farmers the co-operation is above all an effective means for public relations work. Getting to know something inevitably increases understanding, and therefore the farmers have opened the farm gates. Outsider view on the farm work helps the farmers to see things also from another perspective to adjust the communication accordingly. The idea of the co-operation is active participation in various everyday duties on the farm. If the school visits are planned carefully and scheduled to the needs of the farm, the pupils are welcome. They are not used as farm workers, but the activities are planned on basis of win-win principle so as to give the farmer helping hands and new experiences and possibilities to learn by doing to the pupils. Co-operation demands extra effort and time from the farmers' side. As an entrepreneur he is entitled to reasonable compensation. In small pluri-active farms additional income sources are usually greeted with satisfaction. In addition to the need to develop the practicalities and mutual honest feed back, the challenge is to find permanent funding which covers both the schools' extra expenses and the reimbursement for the farmers.

From the schools' point of view the present project deals with developing education by expanding the learning environment outside the classroom, from the farmers' point of view the cooperation deals with diversifying the farm activities as one means of their survival strategy. The aim is that the farm will become established as a learning environment in implementing outside classroom education in schools. Enduring co-operation between schools and farms increases interaction and mutual understanding and strengthens community-based cohesion. The cooperation should not be dependent on individual teachers' personal interest and activity, but it should be incorporated into the schools' educational programs so that it is accounted for already in the curriculum, which is a central tool in school education and in school's daily routines. What is in written form in the curriculum is perceived as important, it becomes transparent, directs the activities and necessary resources are secured for its realisation. 


\section{References}

Åhlberg, M. 2005. Eheyttävän ympäristökasvatuksen teoriasta kestävää kehitystä edistävän kasvatuksen teoriaan. In: Houtsonen, L. \& Åhlberg, M. (eds.) Kestävän kehityksen edistäminen oppilaitoksissa. Hakapaino, Helsinki: Opetushallitus. p. 158-175.

Cantell, H. \& Koskinen, S. 2004. Ympäristökasvatuksen tavoitteita ja sisältöjä. In: Cantell, H. (ed.). Ympäristökasvatuksen käsikirja. Jyväskylä: PS-kustannus. p. 60-79.

Chawla, L. 1999. Life paths into effective environmental action. The Journal of Environmental Education 31, 1: 15-26.

Gretschel, A. (ed.) 2002. Lapset, nuoret ja aikuiset toimijoina: artikkeleita osallisuudesta. Helsinki: Suomen kuntaliitto. 125 p.

Hirsjärvi, S., Remes, P. \& Sajavaara, P. 1997. Tutki ja kirjoita (Research and write), in Finnish. Helsinki, Finland: Kirjayhtymä.

Jeronen, E. 1995. Ympäristökasvatus eettisenä kasvatuksena koulussa ja opettajankoulutuksessa. In: Ojanen, S. \& Rikkinen, H. (eds.) Opettaja ympäristökasvattajana. Helsinki: WSOY. p. 85-93.

Jeronen, E. \& Kaikkonen, M. (eds.) 2001. Ympäristökasvatuksen kokonaismallin tavoitteet ja sisällöt arvioinnin kehittämisen tukena. Ympäristötietoisuus - näkökulmia eri tieteenaloilta. Oulu: Oulun yliopisto Kasvatustieteiden tiedekunnanselosteita ja katsauksia 3. 22-41 p.

Jervell, A.M. 1999. Changing Patterns of Family Farming and Pluriactivity. doi:10.1111/1467-9523.00095. Sociologia Ruralis 39, 1: 110-116.

MMM 2003. Yearbook of farm statistics 2002. Helsinki: Information Centre of the Finnish Ministry of Agriculture and Forestry.

Niemi, J. \& Ahlstedt, J. (eds.) 2006. Finnish Agriculture and Rural Industries 2006. MTT Agrifood Research Finland, Economic Research, Publications 106a Helsinki: Edita. 96 p.

OPH 2004. Peruspetuksen opetussuunnitelman perusteet 2004. Vammala: Opetushallitus. 320 p.

Palmer, J.A. 1998. Environmental education of the 21st century: Theory, practice, progress and promise. London: Routledge. 284 p.

Rantamäki-Lahtinen, L. 2002. Finnish pluri-active farms - the common but unknown rural enterprises. In: Tannevig, H. (ed.). Rurality, rural policy and politics in a Nordic-Scottish perspective. Working paper 1/02. Danish Centre for Rural Research and Development. p. 130-139.

Risku-Norja, H. 2006. The cross-curricular theme Responsibility for the Environment, Welfare and Sustainable Future in the curricula of the municipalities and in the schools' praxis in Finland. School goes to the farm - Finnish-Estonian network for rural-based environmental education. Status quo study. Cited 27 March 2007. Updated 15 December 2006. Available on the Internet: http:IIwww.agronet.fi/maalleoppimaan/Front\%20page/Publications/.

Serageldin, I. \& Steer, A. (eds.) 1996. Making development sustainable: from concepts to actions. Washington, D.C.: The World Bank.

Statistics Finland 2005. Rural indicators (Maaseutuindikaattorit). http://www.stat.fi/tup/tilastotietokannat/index_en.html.

Venkula, J. 2005. Tekemisen taito. Helsinki: Kirjastudio. 155 p.

Venkula, J. 1995. Arki ja tieteellinen ajattelu. Tieteellisen toiminnan ulottuvuuksia III. Yliopistopaino, Helsinki: 169 p. 